\title{
Whither the Crown's Interest in South Island High Country Land Reform?
}

\author{
Ann Brower
}

The South Island high country has long been the subject of debate over resource use and ecological protection. Since early 2006, the ownership and relative value of property rights in high country pastoral leases have become controversial. This article reviews recent research (chiefly Brower (2006) and Brower, Monks and Meguire (in review)) on the law, politics and economics of land reform in the high country.

Flanking the eastern slopes of the Southern Alps, the Crown pastoral estate comprises a full tenth of New Zealand's land area. This pastoral land is owned by the Crown, and leased long-term to farmers for pastoral uses, chiefly extensive grazing and residential occupation. Since 1992, 77 pastoral leaseholds have undergone a gradual land reform process called tenure review, which grants the former lessee full freehold title over some part of his leasehold. The remainder of the leasehold shifts into the conservation estate, to be managed by the Department of Conservation (DoC) as a reserve or park. Between 1992 and 2006, 264,000 ha $(58 \%)$ of those leaseholds were privatised and 193,000 ha $(42 \%)$ were converted to public conservation land (Brower, 2007).

Brower (2006) concluded that tenure review outcomes defy legal and economic logic because the Crown does not defend its legitimate interests during negotiations. This paper uses data on individual tenure review outcomes to test those initial findings, and confirms that tenure review prices are not governed by the strict letter of the law. This is consistent with Ellickson's (1991) findings.

\section{The traditional law and economics hy- pothesis}

Common law conceives of property as a bundle of rights, not a physical object. In pastoral leases, the farmer owns some rights and the Crown owns others. In tenure review, the Crown and the lessee exchange their rights, along with some cash. Conventional law and economics predicts that how much cash the parties exchange depends on who owns which rights, and the rights' value as estimated by empirical economic research.

The value of rights to use land for various purposes has been of some interest to empirical economics. In his study of rural land prices in New Zealand, Stillman (2005) found that land used for extensive pastoralism commanded the second lowest price among all categories of land use considered. The most valued land uses were horticulture and lifestyle blocks. Land developed in any way beyond extensive pastoralism was 2.5 to 14 times more valuable than land used for extensive pastoralism. Though attenuated by the lease contract, the rights to develop land appear more valuable than the rights to graze land (Brower, 2006, 2007).

Who owns the valuable development rights is a matter of legal interpretation. Not surprisingly, there are several competing claims of ownership. The Land Act 1948 and the Crown Pastoral Land Act (CPLA) 1998 stipulate that the lessee holds the right of exclusive pasturage (grazing) and exclusive occupancy (to reside on the leasehold and to exclude trespassers). And he owns the value of all physical alterations to the land (housing, fencing, barns, fertiliser). Moreover, pastoral leases are perpetually renewable, and the rights they grant are transferable and compensable if revoked by the Crown.

Meanwhile, the Crown owns title and all other use rights. Extensive pastoralism is construed so narrowly that a lessee may not even irrigate without Crown consent. Though the Crown has, in certain cases, consented to specific land uses other than extensive pastoralism, Brower (2006) argued that, by virtue of its control rights, the Crown withholds the all-important 


\section{Figure 1: Law and economics hypothesis}

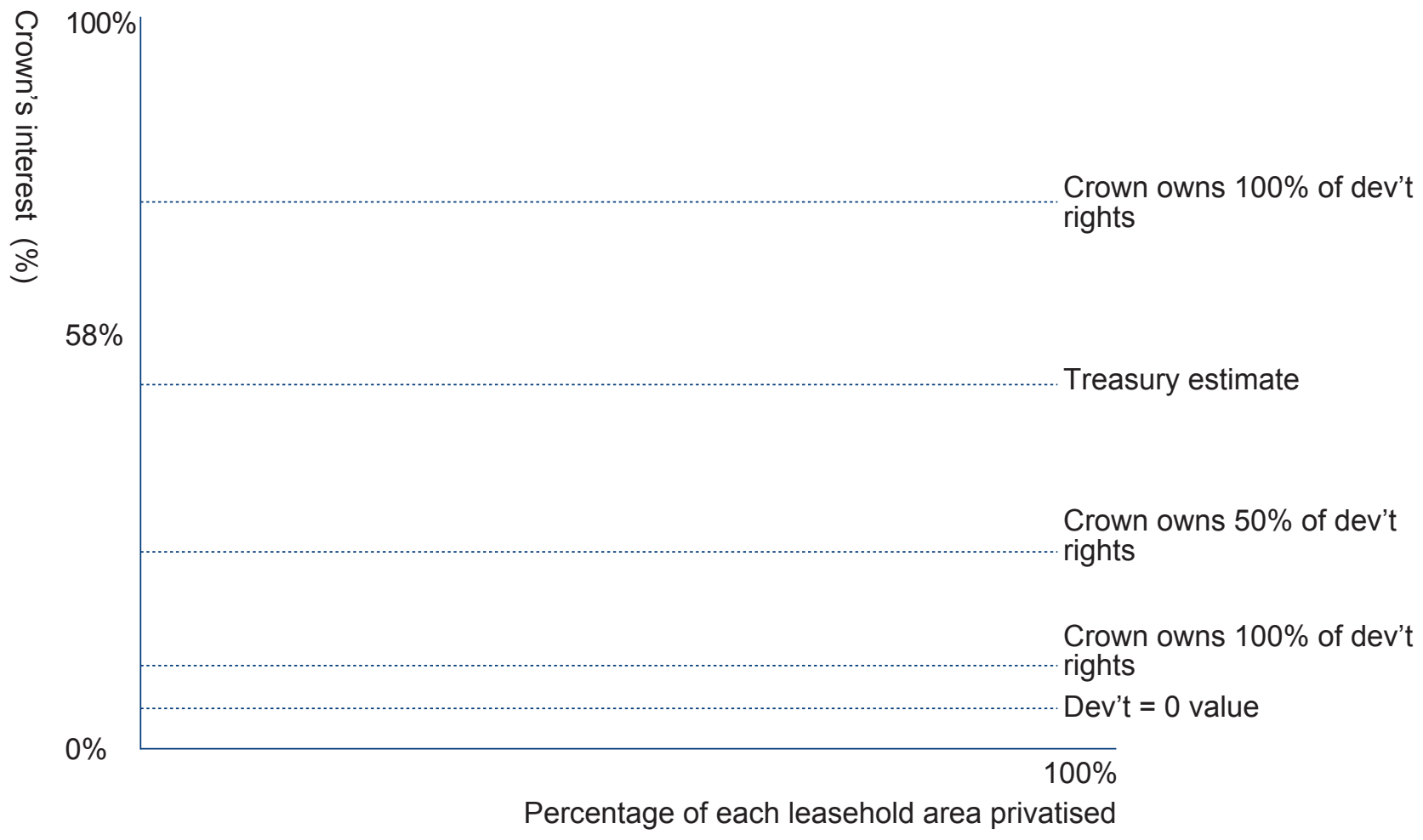

right to develop the land under lease. Under this interpretation, tenure review consists of the Crown's notional purchase of the lessee's rights to graze and occupy the land, and notional sale to the lessee of its rights to adjudicate development of the land. Hence what the Crown sells appears more valuable than what the Crown buys.

Indeed, the New Zealand Treasury (1995) estimated that the Crown's rights in the pastoral estate were worth $\$ 50$ million in 1995; the corresponding lessees' interest was worth $\$ 36.4$ million. Hence the Crown's share of the total value was $50 /(50+36.4)=58 \%$. This fraction is called the Crown's interest (Brower, Monks and Meguire, in review). The remaining $42 \%$ is the lessee's interest. These estimates seem to bear out Brower's (2006, 2007) contention that the Crown should net money under tenure review.

However, some disagree (see Aspinall, 2006; Scott, 2006; Wallace, 2006b; Wallace, 2006c; Gorman, 2006). Some have argued that the Crown does not own the full development rights, so the lessee's interest is more valuable than the Crown's; hence the Crown should rightfully pay lessees. Three variants of this argument appeared in the New Zealand press over the course of 2006:

1 Lessee owns $50 \%$ of the value of development rights: 'The value of these [development] opportunities is shared between the two parties to the contract.' (Aspinall, 2006)

2 Farmer owns $100 \%$ of the value of development rights: 'These potentially valuable unallocated rights have been alienated by the Crown.' (Thomson, 2006; echoed by Armstrong et al., 2006)

3 Development rights have no value, and the Crown's interest is just the net present value of rent: 'The value

1 While tenure review has been controversial for some time, assertions that lessees own some or all development rights are of recent date. Prior to 2006, the only times use rights had come up was in discussions of how much rent the government should charge. Lessees argued that their rents should be low on the grounds that lessees do not own development rights. See, for example: 'Mr Aubrey [then chair of High Country Accord] said any [rent] rise should take into account that ... land was subject to restrictions. "To make an urban analogy, it would be like leasing a gorse-covered section in a town with no right to clear the gorse or right to build a house, with no services laid on such as water, power and sewage. You would have to ask the Crown for permission to undertake any work on the land"' (Otago Daily Times, 22 February 2005). 
of the lessor's interest is no more than the present value of the stream of rental income.' (Evans and Quigley, 2006; echoed by Armstrong et al., 2006)

As economic reasoning predicts that the Crown's interest will be a function of ownership and value of property rights in the land under lease, four claims of ownership yield four variants of a hypothesis. Because ownership is set by statute and does not vary across leaseholds, a scatterplot of the Crown's interest in a leasehold, against the percentage of a leasehold privatised under tenure review, will result in points randomly scattered about a horizontal line. The height of that line will depend on who owns which rights. Four of the five lines in Figure 1 arise from one of the proposed readings of the applicable law, and the fifth arises from Treasury's estimate.

The value of the Crown's interest will vary because leaseholds have idiosyncratic characteristics. For instance, rights to develop lakefront land are more valuable than rights to develop isolated land. But as location is not correlated with percentage privatised (Brower, Monks and Meguire, in review), it will introduce variability in the scatterplot but will not alter the slope of the predicted line.

Improvements might also influence price, because when the Crown buys back the grazing rights in improved land, it must also buy the improvements. But the CPLA also stipulates that land:

1 'capable of economic use' should be privatised;

2 with conservation and recreation value should be conserved '(preferably)' in public ownership (CPLA $\$ 24(\mathrm{a})$ (ii and iii)).

As not every hectare of every lease has been improved, the privatised land is likely to include most improved land because improved land: 1) does not have major conservation value; ${ }^{2}$ and 2 ) is, by definition, capable of economic use.

Hence the Crown compensates for the loss of improvements only if the Crown buys improvements in land that it does not take. The Crown will, of course, compensate for some improvements, but this should not cause the slope of that line to deviate from zero. If improvements do alter the slope of the line, it suggests a serious bookkeeping error, whereby the Crown is behaving like a shopper who pays for something only to leave it at the checkout stand.
In sum, the conventional law and economics hypothesis predicts that the scatterplot will consist of points randomly scattered about a horizontal line. The height of this line reveals the Crown's interest averaged over all deals. The Crown's interest and the size of the Crown payout in turn depend on who owns the development rights.

\section{The apolitical administration hypothesis}

In stark contrast to Treasury's estimate that the Crown would net money in tenure review, Land Information New Zealand (LINZ) annual reports on revenue and expenditures for the years 1992-2005 reveal that the Crown has paid $\$ 18.2$ million more than it has received in payments, with only $\approx 20 \%$ of leaseholds having been reformed. The dissonance between the Treasury prediction and policy outcome suggests that something other than conventional law and economics might be driving tenure review prices.

Indeed, the agency (LINZ) administering tenure review follows a policy-operations split (see Boston et al., 1991, pp.260-5) as follows: decisions about policy direction and political advice to Cabinet are taken by people employed in a division of LINZ distinct from the part that implements policy (the 'operations'). LINZ officials report that tenure review is wholly administered by people employed on the operations side of this split, who are purportedly 'outside the washing machine of politics'. Further, tenure review negotiations are not carried out by LINZ 'operations' officials themselves, but are delegated to contractors from three property management and consultancy firms - Quotable Value, DTZ and Opus. Hence LINZ appears to subscribe to the politics-administration dichotomy, first proposed by Woodrow Wilson (1887), positing that administration can and should be apolitical.

In tenure review implementation, 'apolitical' seems to morph into commercially 'neutral' in negotiations. LINZ instructs the contract negotiators to be neutral, to listen with an open mind, not to advocate for the Crown, and not to take sides in negotiations. Further, several contract negotiators have described LINZ instructions in the following manner: '[They told us

2 In interviews, DoC officials in Canterbury and Otago state that improved land is not likely to be identified as containing 'significant inherent values', hence is likely to be privatised. 


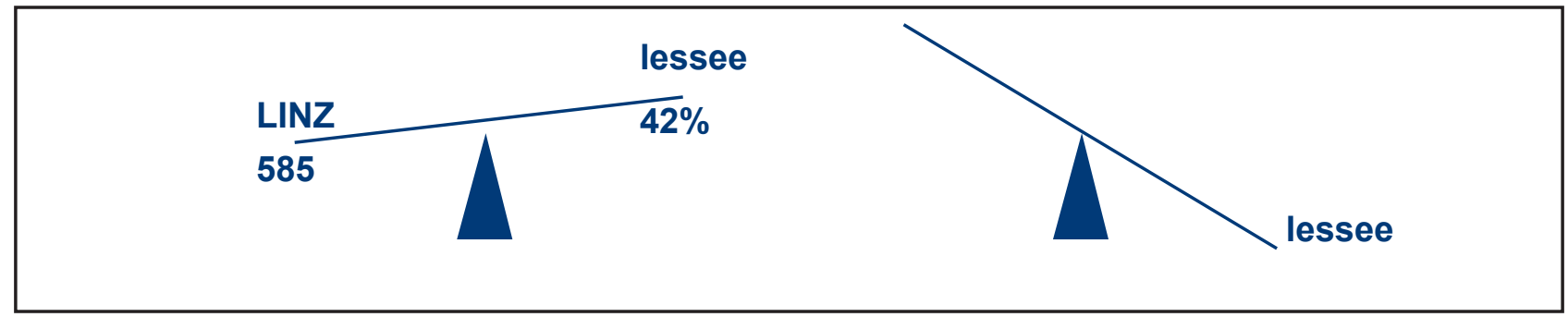

that] it is not our place to drive hard bargains ... The Commissioner and LINZ [officials] have always told us that money should not be a constraint'; 'Money should not stand in the way of a deal'; 'The Commissioner told us we should not hold up the deals for money' (Brower, Monks and Meguire, in review).

However, the Crown retains a financial interest in the land it is re-allocating. Instructing negotiators to be nonpartisan - to avoid systematically favouring conservation over farming land uses (or the reverse) - is defensible. But instructing them to be commercially neutral especially where the financial interest of the Crown is concerned - is less defensible. A non-partisan public service is rightly a prominent feature of New Zealand's Westminster system of government. Nevertheless, it appears that those administering tenure review have made the leap from Westminster's non-partisan civil service to the less advantageous commercially neutral. When the Crown refuses to take sides, the interests of the public are at risk.

To illustrate this, consider the following 'teeter-totter' theory of public negotiations. A teeter-totter teeters up and down as the children riding it cooperate and compete. A 'dominant' child causes his side to totter to the ground with a loud thunk. Similarly, if the Crown advocated for the $58 \%$ interest estimated by Treasury, the power dynamics in the negotiations would look something like Figure 2a. But if the Crown were neutral and avoided advocating for its interest, then the Crown would probably recoup less money than law and economics predicts (see Figure $2 \mathrm{~b}$ ).

In short, the apolitical administration hypothesis posits that failure to advocate amounts to a tacit agreement to lose. In asking 'who is sticking up for the Crown?', Brower (2006, p.3) answered, 'the politics of tenure review remain win-win as long as the Crown agrees to lose'. If apolitical administration indeed leads the
Crown to not advocate for its monetary interest, then the Crown will pay what the lessees want it to pay. Hence the aforementioned scatterplot will reveal a downward sloping relation resembling the lessees' demand curve for freehold land. ${ }^{3}$

\section{Agency theory and the principal-agent hypothesis}

Agency theory tells a story differing somewhat from that of apolitical administration, and paints a somewhat bleaker picture. A principal-agent problem (Niskanen, 1971) occurs when the agent ignores or subverts the principal's goals (Laffont and Martimort, 2002; Ricketts, 2002, ch.5; Waterman and Meier, 1998; Mueller, 2003). Several institutional features of tenure review suggest that it might be subject to a principal-agent problem:

Since 1998 the Crown has been represented in tenure review negotiations by contractors hired by LINZ and employed by one of three property management firms (DTZ, Opus and Quotable Value). These contractors answer to LINZ officials.

Contractors are not paid on commission, but are paid pre-arranged contractual sums for administrative progress towards the ultimate goal (a signed tenure review deal). Hence the Crown does not pay more for a cheap deal or less for an expensive deal, nor does the Crown set a reserve price from which the contractors negotiate.

3 A demand curve predicts someone's willingness to pay for a good. Assuming that a good has a positive value, one will be willing to pay for it. But the price one is willing to pay depends on the quantity she acquires. An individual is willing to pay a high price for $1 \mathrm{~kg}$ of prime steak. But she is willing to pay less per kilo for $20 \mathrm{~kg}$ of steak. At $100 \mathrm{~kg}$ of steak, she is willing to pay very little per kilo. Hence the marginal utility of each kilogram of steak declines with the volume acquired. This translates to a downwardly sloping demand curve. The height and exact shape of the curve depend on what the individual is buying, but demand curves slope down, and she who buys the most steak gets the most generous price. 


\section{Figure 3: Three competing hypotheses (adapted from Brower, Monks and Meguire, in review)}

\section{Law and economics}

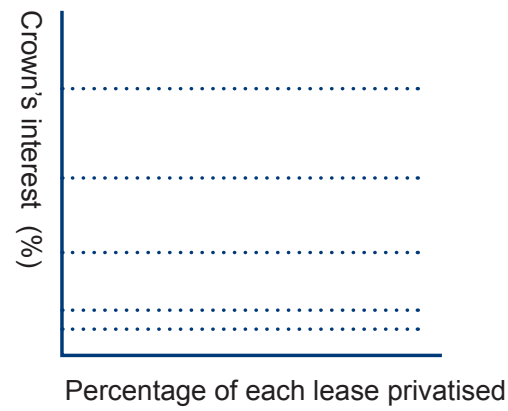

Apolitical administration

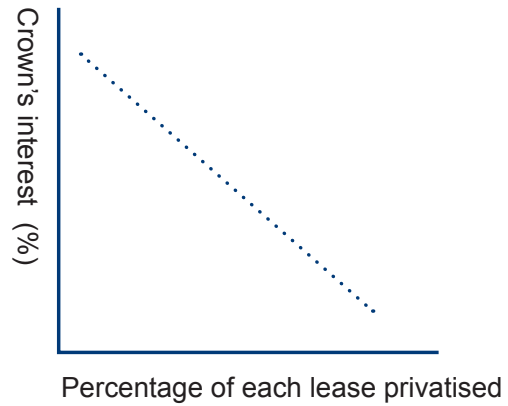

Principal-agent

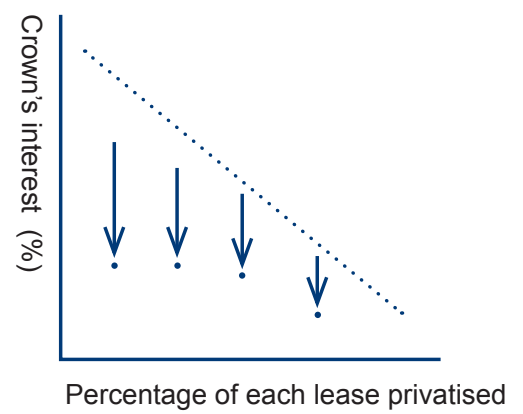

Until August 2006, tenure review outcomes were confidential, giving rise to asymmetric information. Only LINZ and the contractors knew who paid whom how much in a given deal.

Agency theory posits, in short, that agents are most mindful of those outcomes for which they are accountable and rewarded, and least mindful of outcomes for which they are not accountable and not rewarded. When instructed to do X, but rewarded when they do Y, agents often do Y especially when few can ascertain if the agent is doing X, Y, or even Z.

In tenure review, the ministerial principal directs the agents to: 1) complete tenure review deals; ${ }^{4}$ and 2) get a 'fair financial return for the Crown' (Cabinet Policy Committee, 2003, 2005). But contractors are paid when they close deals, being neither rewarded for driving a hard bargain nor penalised for paying too much. The principal-agent hypothesis predicts that agents will follow the principal's directive to close deals, but ignore the directive to be fair to taxpayers. When scatterplotted, the data from easy deals would trace out the lessee's demand curve. But when a lessee drives a hard bargain, the prices would reveal agents' willingness to sacrifice the Crown's interest, and the resulting data would plot below the lessees' demand curve.

4 In 2003 Cabinet encouraged closing deals by setting a deadline that all pastoral leases would have completed tenure review by the year 2008. That deadline has since been relaxed. (Wallace, 2003)

\section{Tenure review outcomes}

In August 2006 the minister of land information consented to release the individual transaction prices (Beston, 2006). These data enabled testing of the theoretical predictions against the data for the 77 deals completed between 1992 and 2006.

Most points trace out a line with a slope of -1 , consistent with the apolitical administration hypothesis and fully inconsistent with any prediction of law and economics. He who gets the most land gets the best price. Sixteen of the 77 dots fall well below this line, indicating that the Crown's interest is even lower, and the review hence more favourable to the lessee, than the apolitical administration thesis predicts. Each of these 16 deals was completed after 1998 and features a Crown payout exceeding \$250,000 (one was $\$ 5.6$ million). Auxiliary variables (rent, easements and location combined) explain only $39 \%$ of the deviation from the diagonal line (Brower, Monks and Meguire, in review).

\section{Discussion}

The declassified prices suggest that price negotiations start - and usually end - on the lessees' demand curve, and that the law of property does not shape tenure review outcomes (Brower, Monks and Meguire, in review). While it is appropriate for lessees to drive hard bargains with the Crown, it is less appropriate for the Crown to readily capitulate. To agree to start negotiations with the other party's demand curve is to agree to lose.

If the apolitical administration hypothesis were wrong, and the Crown were advocating its legal and financial 
Figure 4: Tenure review results 1992-2006

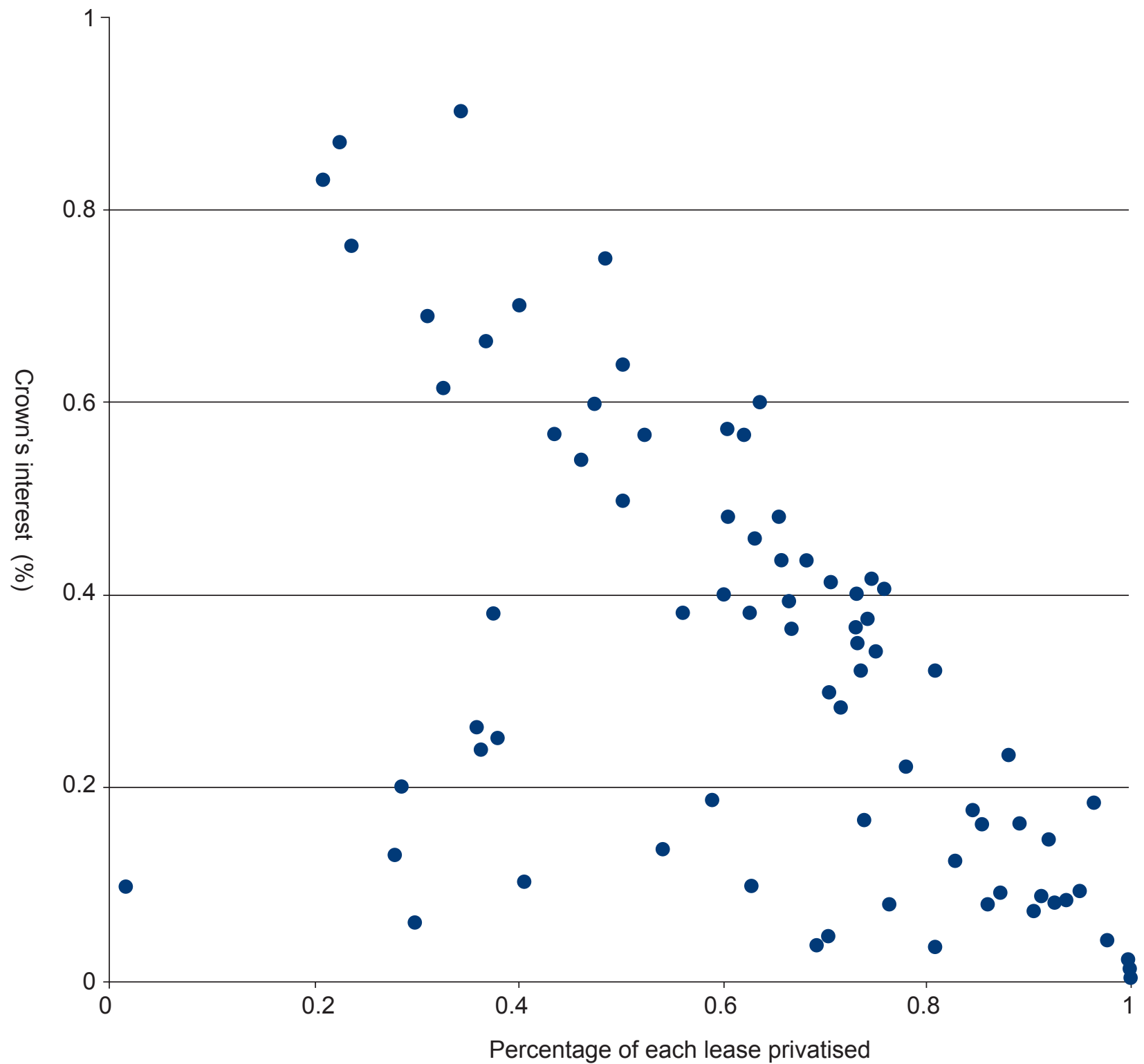

interest, the scatterplot would consist of random deviations from a horizontal line, whose height would depend on the ownership and value of development rights. Even if leasehold ownership held precisely the same value as freehold ownership (as some lessees and their advocates have argued; see, for example, Hutching (2006), citing a lessee), the results would fall along a horizontal line. But tenure review outcomes reject the law and economics hypothesis, regardless of who is assumed to own what.
Having rejected the law and economics hypothesis, and found support for the apolitical administration hypothesis, we turn to principal-agent. If the Crown were sticking up for itself even while negotiating from the lessees' demand curve, a few deals would plot above that curve. Instead, all deviations from that curve are decidedly in the lessees' favour, with a low Crown interest and a high Crown payout. The presence of points below the demand curve and the absence of dots above it suggest that while some lessees drive a 
hard bargain, the Crown never does so. Even within the agree-to-lose negotiation framework, it appears that the Crown is not sticking up for itself.

But these datapoints below the curve emerge only after 1998, when Parliament passed the CPLA and authorised LINZ to administer tenure review (which had begun quietly in the bureaucracy in 1992). The CPLA introduced a new player in the principal-agent equation - the sub-agent. While contractors from only one firm had been accountable to only one principal before 1998, LINZ subsequently became an agent standing between the contractor (who thereby became a sub-agent) and the principal (Brower, Monks and Meguire, in review).

Although apolitical administration and principal-agent are subtly different narratives, their combined effect offers a cautionary tale about governmental negotiation processes. Under the former, the passivity of agents and sub-agents in negotiations with a vested interest leads to results which some would describe as agency or regulatory capture (Selznick, 1949; Stigler, 1971; Levine and Forrence, 1990). Prices that trace the vested interest's demand curve certainly point to the capitulation of capture. But in principal-agent, sub-agents actively facilitate rent-seeking by offering prices even more generous to lessees than capture would predict. Results revealing that some deals are substantially more generous than the demand curve suggest that tenure review makes mere capture look rather attractive.

Two things appear to have gone wrong. First, neutrality and negotiation do not mix. The New Public Management, and the public choice theory on which it relies, offer several tools designed to avoid capture. One such tool is the policy-operations split (see Boston et al., 1991, pp.40, 260-5 for a description and critique of the split). Tenure review negotiations are contracted out of the operations side of the split, which already professes to be politically neutral. This makes it likely that ministerial directions to advocate for the Crown's financial interest will get shunted to the policy side of the split - far from the contractors (Brower, in review).

Second, in contracting, three is a crowd. Ministerial directives to advocate for the Crown's financial interest will dissipate when agents think they should be impartial. They dissolve when the agent, not the principal, sets the contract terms. And they disappear altogether when the agent tells sub-agents to ignore the cost to the Crown. Thus, apolitical administration and principal-agent combine to suggest that ministerial authority over negotiators contracted to the operations side of an agency is attenuated at best. Contracting out of the operations side of a split agency exacerbates capture, rather than avoiding it. Those presiding over future government negotiations would be wise to avoid the same fate.

Finally, the above results measure only the dollars exchanged between the Crown and lessees, not the nonpecuniary opportunity costs. Information asymmetry in agency theory predicts that money is the last thing agents and sub-agents will sacrifice in a negotiation, because it is the outcome most easily measured. In any bureaucracy, measurability means accountability. The non-monetary characteristics of land are harder to measure; hence contractors are less likely to be accountable for them. As such, tenure review negotiators will likely first sacrifice such things as recreation, biodiversity, landscape aesthetics and cultural heritage.

\section{Conclusion}

This article does not criticise, much less condemn, the contractors. But it appears that ministerial directions dissipate, then disappear, in the principal-agent-subagent chain of command. Indeed, agency theory aptly predicts that contractors will heed the directive to close deals (because they are rewarded to do so) and disregard the directive to be fair to the taxpayer (because they are not penalised for ignoring it). Closing the deal at any cost is beneficial to all present at the negotiating table (the agent, the sub-agent and the lessee), at the expense of those absent from that table (the taxpayers) (Brower, Monks and Meguire, in review). Prior to September 2006, even the minister was absent from the table (White, 2006).

In sum, most prices strongly resemble the lessees' demand curve, except when the Crown is even more generous. The results bear no resemblance to the law and economics hypothesis, for all conceivable interpretations of ownership. Tenure review outcomes are consistent with the apolitical administration hypothesis, whereby no one advocates for the Crown and the Crown tacitly agrees to lose. But the most satisfactory explanation for these outcomes is that of agency theory, which predicts that neither financial nor opportunity cost will stand 
in the way of reaching an agreement. This amounts to 'closing the deal at any cost'. One thing is certain: when it comes to property rights in the high country, the law does not rule.

\section{References}

Armstrong, D.J., R.L. Engelbrecht \& R.L. Jefferies (2005) Interim Report: High Country Pastoral Leases Review 2005: a review of pastoral lease rental and tenure review valuation methodologies and outcomes associated with pastoral lands throughout the South Island of New Zealand, Wellington: Land Information New Zealand

Aspinall, J. (2006) 'Myths around tenure review', Otago Daily Times, 28 April

Beston, A. (2006) 'Land-swap farmers sitting pretty, says scientist', New Zealand Herald, 8 September

Boston, J., J. Martin, J. Pallot \& P.Walsh (eds) (1991) Reshaping the State: New Zealand's bureaucratic revolution, Auckland: Oxford University Press

Brower, A. (2006) Interest Groups, Vested Interests, and the Myth of Apolitical Administration: the politics of land tenure reform on the South Island of New Zealand, Wellington: Fulbright New Zealand

Brower, A. (2007) 'New Zealand grazing land reform: background, mechanics, and outcomes', Rangeland Ecology and Management, 60, pp.435-40

Brower, A. (in review) 'When managerialism meets bargaining strategy: the myth of apolitical administration in New Zealand land reform'

Brower, A., A. Monks and P. Meguire (in review) 'Closing the deal: principals, agents, and sub-agents in New Zealand land reform'

Cabinet Policy Committee (2003) 'Cabinet Policy Committee minute of decision', Wellington: Cabinet Office

Cabinet Policy Committee (2005) 'South Island high country objectives', Wellington: Cabinet Office

Ellickson, R.C. (1991) Order without Law: how neighbors settle disputes, Cambridge, Mass.: Harvard University Press

Evans, L. \& N. Quigley (2006) A Review of Ann Lacey Brower 'Interest Groups, Vested Interests, and the Myth of Apolitical Administration: the politics of land tenure reform on the South Island of New Zealand', Rakaia: High Country Accord

Gorman, P. (2006) 'Tenure farmers fire back', Press, 25 November

Hayman, K. (2006) 'Study says tenure review flawed', Press, 23 February

Hutching, C. (2006a) 'Farmers "load their muskets"', National Business Review, 20 October

Hutching, C. (2006b) 'Fulbright scholar raises farmers' ire', National Business Review, 21 April

Laffont, J.-J. \& D. Martimort (2002) The Theory of Incentives: the principal-agent model, Princeton: Princeton University Press

Levine, M.E. \& J.L. Forrence (1990) 'Regulatory capture, public interest, and the public agenda: toward a synthesis', Journal of Law, Economics \& Organization, 6, pp.167-98

Mueller, D. (2003) Public Choice III, Cambridge: Cambridge University Press

New Zealand Treasury (1995) Pastoral Lease Tenure Reform: financial and economic implications, Wellington: The Treasury

Niskanen, W.A. (1971) Bureaucracy and Representative Government, Chicago: Aldine Atherton

Ricketts, M. (2002) The Economics of Business Enterprise, Cheltenham: Edward Elgar

Scott, A. (2006) 'Neutral conclusion draws fire', New Zealand Farmers Weekly, 6 March

Secretary to the Treasury (1995) 'Pastoral lease tenure reform: financial and economic implications, memorandum to minister of finance, deputy minister of finance, associate minister of finance', Wellington: The Treasury

Selznick, P. (1949) TVA and the Grass Roots: a study in the sociology of formal organization, Berkeley: University of California Press

Stigler, G. (1971) 'The theory of economic regulation', Bell Journal of Economics \& Management Science, 2, pp.3-21

Stillman, S. (2005) Examining Changes in the Value of Rural Land in New Zealand between 1989 and 2003, Motu working paper 05-07, Wellington: Motu Economic and Public Policy Research 
Thomson, G. (2006) 'High country report flawed', Press, 8 March

Wallace, N. 'Tenure review nearly completed; environmental group calls for moratorium', Otago Daily Times

Wallace, N. (2006a) 'Farmers dismiss report on tenure review process', Otago Daily Times, 3 March

Wallace, N. (2006b) 'Questions raised over tenure review', Otago Daily Times, 2 March

Wallace, N. (2006c) 'Opinions split on tenure review research', Otago Daily Times, 20 April

Waterman, R. \& K. Meier (1998) 'Principal-agent models: an expansion', Journal of Public Administration Research and Theory, 8, pp.173-202

White, M. (2006) 'High Country hijack', North \& South, November

Wilson, W. (1887) 'The study of administration', Political Science Quarterly, 2 (2), pp.197-222

Ann Brower is a lecturer in public policy at Lincoln University. She specialises in natural resource policy, and the intersection between law, economics and politics. She came to New Zealand on a Fulbright grant, just after completing her PhD at the University of California, Berkeley. This article reflects the Fulbright research and its aftermath.

\section{FIGHTING A FEARFUL DISEASE: Controlling New Zealand's Meningococcal B Epidemic}

\section{An Institute of Policy Studies publication written by Janet Tyson with Richard Norman}

Fighting a Fearful Disease tells of the unique global partnership that, in record time and with a new vaccine, successfully controlled an epidemic of group B meningococcal disease in New Zealand.

It is an in-depth narrative account that covers the scientific advances, the development of policy, and collaboration in practice, as well as the human stories of triumphs and tragedies. It provides a different perspective on the policymaking and implementation process, one that lends itself to both formal and informal teaching and learning.

Published - July 2007

Format - B5 Paperback, pp 296

ISBN - 1-877347-18-3

Price - $\$ 35.00$ (including P\&P within New

Zealand)

To have a copy of Fighting a Fearful Disease and an invoice sent to you, please email, phone, fax or mail your order to:

\section{Institute of Policy Studies}

Victoria University of Wellington

Email ipos@vuw.ac.nz

Telephone +64 44635307

Fax +64 44637413

P0 Box 600, Wellington

New Zealand 